\title{
The European Security and Defence Policy: \\ Defining the European Union as a Rational Actor in \\ International Security
}

\author{
Juan-Camilo Castillo
}

\begin{abstract}
The main objective of this article is to analyze how the European Union, through its Security and Defence Policy, has become a rational actor in international security matters since the end of the Cold War. It will analyze the close relation that exists between European integration and the notion of continental collective security. Also the new post-Cold War concerns that present a potential risk to the EU are going to be examined, and consequently how they affect the rationality of this institution as an actor. Finally the last section will explore the divergence between Europe and America in matters of security and the way this political drift may create a situation in which NATO can become irrelevant in regards of European defence.
\end{abstract}




\section{Introduction}

When the collapse of the Soviet Union in 1991 marked the waning of the Cold War, the role that Europe would play in the new world order was brought into academic inquiry. The fact that fifteen European states were accomplishing their long term goal of integration with the signature of the Maastricht Treaty clearly established that Europe sought to transform itself from the mere stage where the Cold War superpowers went head to head into a significant actor in world politics. Certainly, the European Union has not failed in fulfilling this goal. With 27 member states, a GDP of 13.62 trillion dollars and a population of 486,642,177, the EU has become the world's biggest economy. ${ }^{1}$ Moreover, at a political level, the EU has been actively engaged within various international organizations, is one of the major foreign aid donors, and holds diplomatic relations with a variety of states.

However, the EU's strategic role at a global level still presents itself as a source for debate. As the European Union is easily associated with its economic and organizational achievements, it is often overlooked not only the EU's long standing goal to position as a security actor itself, but also its capacity to perform complex missions around its periphery. Indeed, the paramount normative motive behind the venture of European integration was the objective to bring "stability, peace and prosperity" to the region. Yet, in order to achieve this goal, the concept of defence and force projection cannot be taken out of the equation. ${ }^{2}$ Therefore, it is not surprising to find that the amalgamation of defence capabilities among European states has gained significance over the years. Subsequently, the opportunity to

\footnotetext{
${ }^{1}$ Updated data obtained from the CIA Factbook (available online at: https://www.cia.gov/cia/publications/factbook/).

${ }^{2}$ Holm, Erik. The European Anarchy: Europe's Hard Road into High Politics. Copenhagen Business School Press, 2001, p. 268
} 
build up a collective security arrangement has presented itself as an additional benefited for European integration that has attracted possible candidate states. ${ }^{3}$

The notion of having a united yet self-sufficient Europe in respect to its defence capabilities has been something that various countries in Western Europe were aiming for since process of integration began. Evidently this shows the existent desire to pursue a more autonomous approach to security that would be better established to address specific yet common European interests and concerns. Today, the focus on security has shifted from the former Cold War state-centric approach to a broader perspective that looks at a great variety of security threats such as terrorism, low intensity conflicts and transnational organized crime. Hence, it has become a time for the EU to prove itself as a reliable actor by addressing these emergent threats.

The main purpose of this article is to demonstrate how the EU, through the European Security and Defence Policy (ESDP), addresses its security concerns and defence interests by performing as a rational actor in the global scenario, and consequently, it has become a force to reckon with in world politics. Hence, by examining the connection between integration and collective security, it will demonstrate how the EU has made one of its priorities to acquire its own defence identity. Moreover, through the use of both theoretical approaches and empirical analyses it will be attested the extent to which the EU has achieved this. Finally, this piece will put into perspective how a military autonomous Europe is weakening the cohesion between the EU and the USA, and subsequently, how the ESPD may create a situation of political competition within the West.

\footnotetext{
${ }^{3}$ Cahen, Alfred. The Western European Union and NATO: Building a European Defence Identity within the Context of Atlantic Solidarity. 1989 p. 14
} 


\section{Integration and Security: The Birth of the ESDP}

In order to better understand the role of the ESDP, it is critical to realize the link that exists between European collective security and continental integration, and how this relationship transforms the EU into a key actor in international politics. After more than two centuries of continuous political tension and constant warfare in Europe, the idea of cultural, economic and political interdependence among European states became a widely accepted philosophical principle that offered a tangible solution for the establishment of peace and stability in the region. After the catastrophic outcome of WWII, the ideas of political thinkers such as David Mitrany and Ernst Haas gained legitimacy among leaders and civil society alike, making the concept of trans-national integration into a relevant ideological driving force behind the political developments within the continent. ${ }^{4}$ After a period of forty years with no significant inter-European armed conflicts and tighter multilateral relations (which were a product of various economic and political agreements), the European Union was born in 1992 with the ratification of the Maastricht Treaty, hence materializing the ideal of interdependence into political reality.

However, even before the process of economic and political integration began, many Western European states sought military and strategic cooperation among themselves in order to be able to re-gain their capacity of independent self-defence; which would ultimately protect the delicate political environment that was created in the Post-WWII. Consequently, in 1948 the Treaty of Brussels was signed, giving birth to the Western European Union (WEU) which became the first modern multilateral security arrangement among European nations. In reality, the WEU only came across as a formal treaty with not enough conventional and strategic capabilities to deter a Soviet attack. However, events such as the

\footnotetext{
${ }^{4}$ Jackson, Robert \& Sørensen Georg. Introduction to International Relations, 1999. p. 115
} 
remilitarization of Germany and the end of the dispute over the Saarland through WEU negotiations generated a sense of trust among former antagonist states. ${ }^{5}$ This later opened the door for further cooperation in the economic and political realms among France, Germany and the Benelux. Other earlier attempts for inter-European military alliances were thought of, but never progressed from the preparation stages such as the European Defence Community (EDC) and the European Security and Defence Identity (ESDI), which due to a series of conflicts of interest between the partner states they were never conceived. ${ }^{6}$ It was not after the birth of the European Union in the early nineties that the ESDP was able to take the WEU and other security accords under its wing.

Clearly, the desire for common defence and military cooperation was an ideal that almost every leader in Western Europe had in mind during the Cold War. Initially, the most successful arrangements came in the economic realm; yet, as time progressed, various European states became more willing to surrender autonomy in a variety of fields which facilitated the process for political integration. However, as mentioned above, the possibility of developing a well-established European security arrangement started out with some difficulties and would get momentum only after the European Union proved itself in the 1990s to be a successful experiment. Not surprisingly, like the EU, the ESDP was born from an incorporation of a series of accords instituted to coordinate further collaboration among the signatory states. What is considered to be the first step in this process was the signature of the Saint Petersberg Tasks in 1992; which consisted of giving the WEU the mandate to perform "humanitarian and rescue tasks, peacekeeping tasks, and tasks of combat forces in

\footnotetext{
${ }^{5}$ These were two key events that gave hope to most European states for the possibility of integration, specially taking into consideration that the rivalry between Germany and France for the Saarland region and the strong militarization of Germany were the two main factors associated with the causes of the World Wars and some armed conflicts of the $19^{\text {th }}$ century such as the Franco-Prussian War. Cahen. pp. 4-5

${ }^{6}$ Gordon, Philip. H. "Europe's Uncommon Foreign Policy.” International Security. 1997. p. 83
} 
crisis management, including peacekeeping". ${ }^{7}$ Later in 1997 the signature of Amsterdam Treaty ensured that the Saint Petersberg Tasks would be transferred from the WEU to the European Union as the attempts to integrate both institutions became quite difficult. ${ }^{8}$ Conversely, this legal transfer created the perfect political opportunity for the EU to launch its own approach to defence as part of its existent foreign policy. Subsequently, in 1998, after being hunted by the poor performance of NATO's European forces in the Former Yugoslavia, both the British Prime Minister and the President of France gave a common declaration in Saint Malo stating that it was time for the EU to develop "the capacity for autonomous action, backed up by credible military forces, the means to decide to use them, and a readiness to do so, in order to respond to international crises."9

The Saint Malo declaration defined the purpose of the ESDP and the role it would play in European politics. Even though Britain and France had a historically conflicting perspectives regarding regional security, it became clear that the desire for further autonomy from the United States and NATO was at hand. ${ }^{10}$ Furthermore, this feeling was shared by others of their European counterparts and at the 1999 Cologne European Council the heads of state declared that:

The European Union shall play its full role on the international stage. To that end, we intend to give the European Union the necessary means and capabilities to assume its responsibilities regarding a common European policy on security and defence . . . the Union must have the capacity for autonomous action, backed up by credible military forces, the means to decide

\footnotetext{
${ }^{7}$ Keane, Rory. "European Security and Defence Policy: From Cologne to Sarajevo." Global Society, Vol. 19, No. 1, January, 2005, p. 91

${ }^{8}$ Missorili, Antonio. Background of ESDP (1954-1999). Institute for Security Studies - European Union. 2004, p. 2

${ }^{9}$ Joint declaration given by Prime Minister Tony Blair and President Jacques Chirac in Saint Malo, from Missorili. p.2

${ }^{10}$ Keane, 2005. p. 90
} 
to use them, and a readiness to do so, in order to respond to international crises without prejudice to actions by NATO. ${ }^{11}$

The Cologne Summit marked the birth of the ESDP and, since then, this new institution has notoriously shaped the EU's ability to use military force. Indeed, the EU expects to have a Rapid Reaction Force of 60.000 troops under its direct command by the end of this decade. ${ }^{12}$ Moreover, in the last seven years, the EU has launched numerous deployments all over the world showing its compromise to the Saint Petersberg Tasks. Currently it is possible to see European forces in peacekeeping/peacemaking operations in the Balkans, West Africa, the Levant and South Asia. Bastian Gieregich and William Wallace argue that it is nothing new for European nations to be involved in overseas deployments; however, what is a novelty after the Cologne declaration are "the involvement of so many states acting together, and the toughness of the tasks and rules under which they are operating." ${ }^{13}$ In fact, according to the research done by Gieregich and Wallace, the number of troops sent by Europe in missions overseas has doubled in the last ten years. ${ }^{14}$ Therefore, these developments demonstrate how the ESDP has triggered a 'paradigm shift' in the strategic culture within the EU, which has been distancing itself from the standbydefensive regime imposed by NATO during the Cold War and embracing instead an active role in military operations.

Finally, it is worth mentioning the success that the ESDP had in bringing together member states that were somewhat marginal in matters of regional security. For instance, even though Ireland has traditionally had a neutral stand regarding foreign policy (which

\footnotetext{
${ }^{11}$ Statement of the European Council held in Cologne, from Haine, Jean-Yves. ESDP: an Overview. Institute for Security Studies - European Union. 2004, p. 3

${ }^{12}$ McCormick, John. Understanding the European Union: A Concise Introduction. 2005. pp. 218-19

${ }^{13}$ Gieregich, Bastian. \& Wallace, William. "Not Such a Soft Power: The External Deployment of European Forces." Survival. Vol. 46. No. 2. Summer 2004. p. 169

${ }^{14}$ Gieregich, Bastian \& Wallace, William. p. 178
} 
involves not being part of NATO nor WEU), it has actively participated in ESDP operations and UN operations where there are large contingents of European forces. ${ }^{15}$ By the same token, other countries with a longstanding history of neutrality such as Austria, Finland and Sweden, have partaken in multiple ESDP operations. ${ }^{16}$ Furthermore, these countries were the main lobbyists behind the transfer of the Petersberg Tasks from the WEU to the EU in 1997 clearly showing their desire for an EU-sponsored security arrangement. ${ }^{17}$ The ESDP has proven to be a very efficient framework that has politically synchronized states with different approaches to defence and security. Initially, it became a surprise to see Britain-a traditionally 'Atlanticist' state—agree with France_a prime 'Europeanist' state—in the need of making the EU more strategically significant. However, what has been even more interesting is the manner in which EU neutral countries decided to integrate within the ESDP.

\section{A Brief Theoretical Analysis of the EU's Role in International Security}

For students of International Relations, the success of the European Union and the role it plays globally has proven to be a constant challenge to the established paradigms in the field. In fact, this defiance gains more complexity as the ESDP gives further autonomy to this organization by providing the EU with the ability to use coercive force. Customarily, when speaking about matters of international security in the IR discipline, the most influential paradigms adopt a position in which the state is the sole actor responsible for the "causes of war and conditions for peace." ${ }^{18}$ However, since the ESDP presents the EU as an

\footnotetext{
${ }^{15}$ Strategy Statement 2005-2007. Department of Defence, Ireland. Publication available online at: http://www.defence.ie/WebSite.nsf/Publication+ID/C3700595684613A1802570C80055B722?editDocume nt

${ }^{16}$ Gieregich \& Wallace. p. 173

${ }^{17}$ Missorili p. 2

${ }^{18}$ Holsti, K. J. The Dividing Discipline: Hegemony and Diversity in International Theory. 1985. pp. 15-19
} 
actor that has acquired the capacity to administer force, just like a state, the traditionalist hypotheses become ineffective in understanding this institution. This phenomenon, as the scholar Adam Bronstone points out, confronts traditional IR theories (especially the realist and liberal traditions), which fail to explain the intricate functionality of integration and the capacity to apply common security policies for all member states. ${ }^{19}$ Nonetheless, this opens the opportunity to use alternative theoretical models that could assist in the comprehension of the nature of the EU's role and behaviour as a significant security actor.

In their article The Politics, Power and Pathologies of International Organizations, M. N. Barnett and M. Finnemore proposed a hypothetical model that treats international organizations as rational actors, based on the sociological assertion that they are behavioural bureaucratic entities capable of acting in an autonomous manner. We can trace the origins of this paradigm to earlier IR theories that sought a pseudo-ontological role for international institutions. Functionalism, which has been commonly used to approach the EU, comes across as one of these first theories which suggested that over time states would give leeway to a specific International Organizations (OI) due to the benefits brought by membership. Consequently, the organization would find itself in a position where it could acquire “jurisdiction over preceding states." ${ }^{20}$ However, in Barnett's and Finnemore's argument, the international organizations' power and autonomy comes from two very specific sources: the legality of the values they represent and the control they have over "technical expertise and information." ${ }^{21}$ This, unlike the more optimistic views of the functionalist and neo-

\footnotetext{
${ }^{19}$ Bronstone, Adam. "IR Theory and the EPC/CFSP: The Case for a Different Approach." European Security into the Twenty-First Century. 2000 p. 181

${ }^{20}$ Ernst Haas being quoted in Martin, L. \& Simmons, B. "Theories and Empirical Studies of International Institutions." International Organization. 54:2. 1998. p. 735

${ }^{21}$ Barnett, M. N. \& Finnemore, M. "The Politics, Power and Pathologies of International Organizations." International Organization. 53:4. 1999. p. 707
} 
functionalist approaches, leaves space to judge the performance of international institutions. Barnett and Finnemore acknowledge the existence of international organizations that fail to fulfill their intended purpose. ${ }^{22}$ Nevertheless, they argue that due to the normative the IOs represent and their bureaucratic structure it is very unlikely to see their autonomic pursuit of interests in jeopardy.

If Barnett's and Finnemore theorem is applied to the EU's ability to work as a strategic actor, the result is staggering. In comparison to nomal IOs, the European Union has already an extensive level of autonomy and a great competence to persuade or influence its member states. Furthermore, the existence of supranational bodies and the pervasive cooperation that exists among member states gives the European Union a high degree of authority to preside over them. ${ }^{23}$ Hence, through the ESDP, the EU should have the ability to command military strength from its member states in order to accomplish specific goals or interests, which are beneficial for both the organization itself and its members. This ability is expected to increase in the years to come as the compatibility between national forces and the command organization becomes more effective (i.e. European Rapid Reaction Force.) However, what makes the EU a rational actor and not merely and autonomous one is its capacity to act according not only to its interests and concerns, but also according to its limitations. Indeed, while the EU is known for often using soft power as an integral part of its foreign policy, when it comes to the use of coercive force, the EU is more likely to act under certain parameters in order to maximize its utility. The raison d'être behind the European Union is to maintain peace and stability within its borders, and for that reason, we

\footnotetext{
${ }^{22}$ Ibid.

${ }^{23}$ McCormick, J. pp. 126-27
} 
can see how military action presents itself as a viable mean against significant threats that may directly or indirectly affect this stability.

Now, if we consider the assumption that the EU works in a fully autonomous manner, and we apply it in a Rational Action Model, it is possible to see how there are certain variables which facilitate or limit the implementation of force. By no means are these variables the sole conditions which influence the use of coercive force; however they are present in most empirical and are useful for the purpose of this article. The first variable to consider is the extent to which the threat can disrupt the status quo of peace and stability within the EU. The second variable is the length to which the elimination of a potential or external threat will provide a better outcome or position for the organization. The third variable is the normative value the action would have; and finally, the last variable is the cost of the endeavour. In order to better understand these variables we can represent different contemporary conflicts (which are not necessarily armed) in the form of possible actions:

$$
\text { (i.e. } \left.A=\left\{a_{1}, \ldots, a_{i}, \ldots, a_{j}\right\}\right) .^{24}
$$

Thus, we can obtain a model that looks like this:

$$
A=\{\text { Internal Conflict W. Africa/Levant, Iran's Nuclear Program, Internal Conflict }
$$

\section{Colombia\}}

In this case, the result in the form of strict preference would be:

$$
A=\{\text { Internal Conflict Africa/Levant }\}
$$

The main reason behind this result is the presence of the four variables mentioned before in this strict preference. Undeniably, the Levant and Western Africa are regions of interest for the EU where there is extensive economic and political investment. Apart from that, a

\footnotetext{
${ }^{24}$ The mathematical representation for Rational Action Model (RAM) was obtained from: Arrow, Kenneth J.. "Economic theory and the hypothesis of rationality," The New Palgrave: A Dictionary of Economics, 1987. pp. 69-75.
} 
conflict in these regions could have repercussions in Europe in the shape of illegal immigration, transnational crime and disruption in economic production. ${ }^{25}$ Also, as humanitarian violations occur as consequence of the domestic armed conflict, it becomes necessary for the EU to act as part of the Saint Petersberg Tasks mandate. Finally these two regions are within the range of the capabilities that most European militaries have for force projection (i.e. C-130 or A400 Cargo airplanes). Consequently, to be engaged militarily in these regions is in Europe's best interest.

In the case of Iran, some of the variables are met, but not the majority. Therefore, we can see how the EU would rather use soft power in order to disengage this possible threat (i.e. the EU3-Tehran Agreement). ${ }^{26}$ Indeed, starting an armed conflict with Iran over their obscure nuclear program would bring more costs than benefits at a devastating level. For that reason, only in the occasion that Iran would undertake a hostile action against Europe the majority of the variables would be met, and thus, it would be in the EU's best interest to protect itself from an eminent threat. Also, if we look at the last option proposed in the model, there are almost none of the variables met, clearly indicating that the EU will use exclusively soft power in order to address this issue. ${ }^{27}$ As a result we can conclude that the EU has the capacity to act as a rational actor in matters of security as it uses coercive force in selective occasions where its stability is at stake or certain interests can be satisfied. In the next section a variety of threats and security interests will be examined.

\footnotetext{
${ }^{25}$ Chancellor Merkel of Germany highlighted the fact that what happens in Africa may have repercussions in Europe in a speech held in the G8 Summit 2007 in Heiligendamm. Transcript of her speech " Africa: a continent with huge potential" is available online at: http://www.g-8.de/Content/EN/Artikel/2007/05/200705-22-afrika-kontinent-mit-potenzial_en.html

${ }^{26}$ An electronic copy of the EU-Tehran agreement document is available in the IAEA website at: http://www.iaea.org/Publications/Documents/Infcircs/2004/infcirc637.pdf

${ }^{27}$ More information the the EU's role as a broker in negotiations between the Colombian government and the FARC is available at: http://ec.europa.eu/external_relations/colombia/intro/index.htm
} 


\section{European Security Concerns in the $21^{\text {st }}$ Century}

With the fall of the Soviet Union in 1991, the dissolution of the Warsaw Treaty Organization, and the slow integration of Central-Eastern Europe into the continental sphere, the EU has experienced a rapid shift of focus in security matters. With the end of the Cold War, new potential threats have surfaced, ones that challenge the conventional defence approaches undertaken post-WWII. In many respects, most of the security concerns do not affect all member states equally due to different factors such as geographical location, historical background and economic interests at a regional or global level. However, as the neo-functionalist school of thought argues, the economic and political interdependence that exists under the European Union has put most states in a position where their approach to common issues or a specific problem that could disrupt the normal functioning of a member have become evenly relevant security concerns. ${ }^{28}$ Also, as the European Union itself has become an autonomous and rational actor, it is in its best interests to protect the regional stability.

For the purposes of this paper, I will classify the main security concerns that Europe faces today into three general categories that are able to put into perspective the ways in which these feasible dangers may affect the continental stability. The first category groups the domestic concerns which relates to potential threats that exist within the boundaries of the European Union or other associated states in the continent. The second category will encompass the regional concerns, which are the threats that exist outside the borders of the EU, yet due to their close proximity at a geographical level, they present an existent danger to one or more member states. Finally, the last category is related to global concerns which

\footnotetext{
${ }^{28}$ The functionalist theory argues that countries with strong economic or political ties cooperate in order to satisfy common goals. Caporaso, J. "Regional integration theory: understanding our past and anticipating our future." Journal of European Public Policy, 5(1). 1998. pp.1-16.
} 
its primary focus is on potential security risks that threaten economic or political interests that the European Union may have in any part of the world.

With the integration of various states within the EU, certain domestic security issues, which may exist in a particular or various states, are able to cross borders hence transforming into trans-national issues. In regard to this, we are able to identify two main concerns that have been present in the continent since the early $20^{\text {th }}$ century: domestic terrorism and organized crime. The former is a problem that, in most cases, is related to pre-Second World War political or cultural predicaments. For instance, we can trace the origins of the IRA in Northern Ireland or the Basque separatist ETA in Spain back to the regionalist movements of the late $19^{\text {th }}$ century. ${ }^{29}$ Therefore, it is important to understand that various European states have an extensive level of experience dealing with this issue. In addition, it is worth noticing how in the last 20 years different national security services and law enforcement agencies have worked closely in order to combat these illegal armed groups. In the case of ETA for example, the mutual cooperation and joint operations between neighbouring states (Spain and France), have become invaluable tools that helped to put pressure on the terrorist band and capture many of its key affiliates. ${ }^{30}$ Moreover, as terrorism has become a global issue with domestic implications, it is possible to see how domestic agencies of the EU such as Europol work hand in hand with the ESDP. ${ }^{31}$

Organized crime is another trend with a long history of being a significant concern in Europe. It is believed that it emerged as a side effect from the socio-economic disparity that

\footnotetext{
${ }^{29}$ Dorman, Andrew. \& Treacher Adam. European Security: An Introduction to Security Issues in Post-Cold War Europe. 1995, pp. 144-145

${ }^{30}$ In the last ten years, various members of ETA have been captured thanks to successful Franco-Spanish joint actions in towns along the Basque border. BBC News. 03 October 2005. http://news.bbc.co.uk/2/hi/europe/4305062.stm

${ }^{31}$ Den Boer, Monica. \& Monar, Jörg. "Keynote Article: 11 September and the Challenge of Global Terrorism to the EU as a Security Actor," JCMS: Journal of Common Market Studies 40 (s1), 2002. pp. $18-19$
} 
surfaced in urban centres as a consequence of the Industrial Revolution; however, it became into serious international problem once globalization started to facilitate the movement of goods, information and people in the 1960s/70s. ${ }^{32}$ Certainly, the opening of borders within Europe has left the region vulnerable to these criminal groups. Subsequently, the illicit traffic of drugs, humans, weapons and the violence that comes with it represents a real hazard against European citizens, communities, and the states themselves. ${ }^{33}$ Thereby, as Markus Ekergren argues, it is possible to see how in the European context the term of security threats broadens to include domestic criminal activities within one or more states, and consequently the ESDP will have to work in conjunction with the judicial branch of the EU in order to fight against illegal activities which may affect the wellbeing of any member state or the continent as a whole..$^{34}$

The second category of European concerns in continental security include what can be classified as regional concerns, which are basically any potential dangers that are located in the proximity of the European Union's boundaries. Sven Biscop argues that there are four main politico-military threats which exist towards Europe on the Mediterranean boundary, these are; weapons proliferation, radical Islamism, terrorism and military threats (which is meant for the use of conventional force by one or various states). ${ }^{35}$ In fact, in the last twenty years Europe has actually come face to face with most of these threats. Some examples of there are the use of Scud missiles by Libya towards US naval bases in Italy, Islamic terrorism in Rome, Madrid and London, the invasion of the Perejil Islands by Moroccan seamen, the

\footnotetext{
${ }^{32}$ Williams , Phil, “Transnational Criminal Organisations and International Security,” Survival, Vol. 36, No. 1, Spring 1994, p. 97

${ }^{33}$ Ibid. p. 110

${ }^{34}$ Ekengren, Magnus. "From a European security community to a secure European community." CFSP Forum. 2005, pp. 5-7.

${ }^{35}$ Biscop, Sven. Euro-Mediterranean Security: In Search for a Partnership. 2003 pp. 12-16
} 
acquisition of ballistic missiles by North African and Levant countries, and their capability to obtain chemical, biological and nuclear technologies. ${ }^{36}$ The Mediterranean has become an important geo-political arena for the ESDP due to its economic and political importance. It is imperative not to forget that the Mediterranean still is one of the main highways for resources such as oil and minerals that come from the Middle East and Sub-Saharan Africa to Europe. Nevertheless, the same concerns can be applied to all the peripheral regions that surround the continent. Biscop's politico-military threats can be found in other regions in close proximity such as the Caucasus and Central Asia, which not only contain similar security risks for the region, but also have an important economic value in natural resources such as oil and natural gas among others.

Finally, the third category of security issues refers to the global concerns that the European Union or its member states may have at any location in the world. Many of these are in countries that were under the sphere of influence of imperial powers such as the former colonies of Britain, France, Belgium, the Netherlands, Spain and Portugal. Consequently, various European states have acted as stabilizers in places where violence and humanitarian disasters have taken place, which in most cases are the legacy of the harsh imperialistic policies that these nations imposed in the first place. ${ }^{37}$ However, it is hard to ignore that many of these volatile locations possess valuable resources as well, those necessary for the manufacture of goods in Europe, implicating that in some cases the intervention of the European Union or one of its member states in these regions may also take place in order to protect specific economic interests overseas. For instance, the ESDP Operation Artemis had as its main priority to stabilize the north-eastern province of Ituri in the Democratic Republic

\footnotetext{
${ }^{36}$ Ibid. pp. $18-21$

${ }^{37}$ Dorman \& Treacher. pp. 154-155
} 
of Congo, and there is evidence that the French government was planning to launch a deployment if the ESDP mission was not approved. ${ }^{38}$ The significance of this is that the Ituri province has one of the biggest precious metals deposits in Africa where many European companies (mainly French and Belgian) had extraction operations. However, it is important to note that this region has experienced one of the bloodiest internal conflicts in modern history where 2.5 million were estimated to be killed by different warring factions fighting for the total control of the natural resources of the province. ${ }^{39}$

In sum, the European Union focuses on specific security issues that have the potential of disrupting its economic and political functionality as well as the stability of its member states. Many of these threats can be traced as consequences of the geo-political location in which the continent encounters itself, and also to the products of the political, social and military history of the region. However, it is important to point out how, under the ESDP, these issues are seen in a regional context and not only a national one. In this sense, a security threat is not only assessed by the level of damage it can cause to an specific state, but also by how it can affect Europe as whole. It also gives the different governments a chance to cooperate in order to address common security issues in concert, therefore they are able to deal with any threat in a more effective way, which has a major political, economic and military weight in comparison to what a single state would normally have.

\section{The Eroding Cohesion in Transatlantic Security Approaches}

The dismantling of the Soviet Union and the Eastern Bloc in the early 1990s created a situation in which both the western European nations and the United States lost their

\footnotetext{
${ }^{38}$ Keanne, p. 94

${ }^{39}$ Number obtained from Neack, Laura. "Peacekeeping, Bloody Peacekeeping," Bulleting of the Atomic Scientists. Volume 60, Number 4 / July/August 2004. p. 47
} 
common ideological enemy. With this, the focus on defence shifted from a potential full scale war with the East to the new dangers that are associated with less developed countries where deteriorating socio-economic conditions have become harvest fields for new potential dangers such as international terrorism. In this context, Europe started to define its own approach towards security issues. The emergence of political ideologies such as Gaullism, demonstrated the willingness of governments to manage international affairs independently from the American clout. However, due to the economic aid that Western Europe depended of in order to rebuild itself after WWII and the military umbrella that the Americans offer to balance out the Soviet Union and the Warsaw Pact, it became extremely difficult to manage things without Washington's consent. Yet, thanks to the economic revival in the second half of the $20^{\text {th }}$ century and the positive results in the experiment of continental integration, the European Union has been able to approach questions of foreign policy according to its own needs, interests and limitations, which consequently has led to a disparity between European and American foreign policy making. The gap between the European and American approaches to global security issues has become more evident in the last seven years, making it clear that there is an inconsistency between the methodologies that the two parties may have.

In his article, Power and Weakness, American neo-conservative scholar Robert Kagan argues that the reason behind this separation between European and American interests and approaches in the field of defence and security rests on the fact that the US has maintained its position as a military superpower while the European Union has failed to reach similar standards, dismissing the neo-realist theory of a post-Cold War era in which Europe, China and Japan would obtain the status of military superpowers and subsequently 
creating a new multi-polar order in the global system. ${ }^{40}$ In Kagan's view, the approaches that the US and EU pursuit are dictated by their military capabilities and by the percentage of their GDP which they spend in defence. ${ }^{41}$ Kagan's argument clarifies the reason why the US is more susceptible to take a confrontational approach towards an issue, while Europe would rather use soft power as its first option.

Furthermore, the constraint in military expenditure by the EU can also elucidate the reasoning behind the ESDP's prioritization of threats that are positioned close to home, instead focusing its attention towards other issues that exist in a global level. Indeed, Catherine Gegout and Marie C. Fellow, two scholars from the London School of Economics, argue that policies taken by the ESDP such as the European Security Strategy aim "mainly to protect European security, rather than focusing on Global security" and consequently illustrate "that the EU is a strategic actor focused on short-term [European] security." 42 The reasoning behind this argument is the fact that the existing limitation in the military capability of the EU in comparison to the US has forced Brussels to prioritize the threats it can only cope with based the level or risk they pose and their geographical proximity. Thus, in the event that the EU finds itself in a position where it requires the use force, it would rather use it in a peripheral region rather than in remote areas such as the Far East.

Other factors are also important to take into consideration in order to understand the gap between the American and European defence approaches and capabilities. The Director General in the Directorate General External Relations of the European Union, Robert Cooper,

\footnotetext{
${ }^{40}$ Kagan, Robert. Power and Weakness. Policy Review. 2002. available online at: http://www.hoover.org/publications/policyreview/3460246.html

${ }^{41}$ While the US spends $\$ 500$ billion per year in military expenditures, Europe only spends $\$ 160$ billion per year (Although this figure has changed since 2006, now the defence budget of Europe is around $\$ 250$ million). Ibid.

${ }^{42}$ Gegout ,Catherine and Fellow, Marie C. "Europe has a strategy, but is the EU a strategic actor?" CFSP Forum. Vol. 32005 pp. 8-9
} 
responds to Kagan's arguments by pointing out a number of aspects that are ignored in Kagan's analysis. ${ }^{43}$ The first one would be the fact that the EU forces have to go through an evolutionary process in which the military elements of each member state have to become compatible with one another at a technical level in order to be able to respond to any threat globally. ${ }^{44}$ This point has been widely overlooked in the academic community especially if we take into consideration that several Western European states support their own armed forces through national military industries that supply specific combat material, while at the same time there are others that rely on foreign weaponry (which comes from various sources such as America, other European countries and even surviving equipment from the former Warsaw Pact).

The second point in Cooper's argument is the fact that the European low-politics approaches to certain issues are indeed a product of a non-violent post-modern European mentality rather than just a consequence of the lack of military power as Kagan states. ${ }^{45}$ Although this view it is somewhat Eurocentric, many Europeans believe that the economic interdependence formula that worked in Europe can work in other parts of the world. In fact, various approaches taken by the EU towards certain issues are based on the historical experience that one or various member states may have in respect to the same or similar issues. For instance, in the case of terrorism, Europe has a long history of dealing with groups such as the IRA, ETA, the Red Army Faction and the Red Brigades, which performed terrorist acts such as the use of improvised explosive devises, extortions and kidnaps against

\footnotetext{
43 Cooper Robert. “The European Answer to Robert Kagan.” Transatlantic Internationale Politik. 2003. p. 19-20

${ }^{44}$ Ibid. pp 19-25

45 This refers to the notion that the main reason for Europe's choice of low politics instead of high politics goes to the idea that most European States try to avoid continuity of the continent's violent history of the last 200 years. Ibid.
} 
both the civilian population and specific political targets. Hence, it is possible to see why "terrorism is still seen as a crime problem [in Europe], and not an occasion to go to war."46 This makes it clear how there is a diverging perception between the responses in international security that Europe and United States are likely to have.

This section established how the European Union has developed its own policies and approaches towards security issues on a different path from the ones of the United States. Factors such as constraints in military capabilities, immediate concerns and historical background, play a role in shaping the way in which the EU acts in the global scenario. The divergence in approaches that exists nowadays in the West has become a clear indicator of how the European Union has been able to develop into a rational actor in matters of security and defence.

\section{The ESDP and NATO: A Transition In Collective Security?}

With the cohesion between the EU and US growing weaker in issues of security, defence and military interests, the former Western Bloc is experiencing disintegration as the two main parties pursuit their own paths. Thus, NATO is at risk of becoming obsolete due to the fact that the divergent interests in foreign policy possessed by both the European and North American components are at risk of becoming incompatible. Nevertheless, there are still many 'Atlanticists' such as Robert E. Hunter, whose arguments are in favour of the necessity which the ESDP and NATO have of working together in order to protect existing common interests and "maintain the security of the transatlantic region." 47 In other words, according to the Atlanticist view NATO is still an invaluable political tool that is as functional for both Europeans and North Americans alike and therefore it is able satisfy the necessities of both sides, even though these have been diverging since the last stages of the Cold War.

\footnotetext{
${ }^{46}$ Leiken, Robert S. “Europe's Angry Muslims.” Foreign Affairs. Vol. 84. 2005 pp. 129-130

${ }^{47}$ Hunter, Robert E. The European Security and Defense Policy: NATO's Companion or Competitor. 2002.
} 
In other words, according to the Atlanticist view NATO is still an invaluable political tool that is as functional for both Europeans and North Americans alike and therefore it is able satisfy the necessities of both sides, even though these have been diverging since the last stages of the Cold War.

However, for many the Atlanticist view has become as obsolete as the institution they are trying to defend. According to Owen Harris, the concept of "the West" ceased to exist with the end of the Cold War, and therefore the principle behind NATO is gone. ${ }^{8}$ Also, most European states, as it has been stated throughout this piece, always had a desire for a more autonomous approach to current threats, rather than a general Western one that would be predisposed by the United States. Therefore, the ESDP as an institution allows the European Union to satisfy its necessities in respect to security and defence matters in a more specific way which works towards the common interests of its member states and the organization itself, while, on the other hand, NATO's more broad approach to security may become incompatible in respect to European concerns.

The criticisms towards a crumbling NATO go further than just an empirical observation of the division between North America and Europe. Many critics believe that there is a division existent among the European states as well. The conflicting stands that were taken by the leaders of various countries towards the question of Afghanistan and especially Iraq made many experts believe that the West was breaking into smaller fragments. However, many scholars saw this situation as a learning experience in which the ESDP would be able to explore its strengths and flaws. For example, Anand Menon believes that the Iraq crisis in Europe helped the different governments of the EU (and especially the ones from Britain, France and Germany) to understand and solve possible complications that may exist within the ESDP, therefore presenting the crisis as a situation from which the institution has

\footnotetext{
${ }^{48}$ Harries, Owen. "The Collapse of the West." Foreign Affairs. Vol. 72. 1993. pp. 41-42. Carpenter, Gallen. Beyond NATO: Staying out of Europe's Wars. 1994 p. 145
} 
benefited itself. 49 It is important to take into consideration the fact that the ESDP is a young institution that it is evolving at a fast rate, and for that reason controversial events such as the war in Iraq can help to prepare the European Union in becoming a more effective strategic actor. Also, it is essential to remember that the ESDP has been able to surpass the divisions created by the Iraqi situation and consequently has been working at full strength in more relevant scenarios for Europe such as Sub-Saharan Africa and Afghanistan.

By the end of the Cold War, many analysts predicted a significant structural change in regard to the international security system. The prominent realist scholar Kenneth Waltz believes that "NATO is a disappearing thing. It's a question of how long it's going to remain a significant institution even though its name might linger on." 50 As a result, it is not surprising that in coming years the relevance of NATO will decrease, particularly at a time where most international security threats are located in the global south. This may also at some point create a situation in which the role of the ESDP in respect to regional security will become more relevant for most European nations; which subsequently would create a situation in which NATO could be become politically insignificant.

\section{Conclusion}

In conclusion, we can consider the European Union an autonomous and rational actor in the realm of international security. Indeed, this is a challenge for traditional approaches to IR where the state has been seen as the core actor of the international system. However, by examining two different hypothetical tenets it is possible to visualize the extent to which the EU acts according to its own interests, concerns and limitations. The ESDP has provided the European Union with this capacity after a long and somewhat difficult process of defence integration. For that reason, when we look at this specialized agency of the EU it is important to understand that it goes further from just being a novel security arrangement; it

\footnotetext{
${ }^{49}$ Baldwin, David A. (ed.). "Institutionalist Theory and the Realist Challenge After the Cold War." Neorealism and Neoliberalism: The Contemporary Debate, 1993, pp. 286

${ }^{50}$ Menon, Anand, From Crisis To Catharsis: The ESDP after Iraq. International Affairs. 80:4, 2004. pp. 641-642
} 
actually represents the authority that the EU has as a rational actor to use coercive force, soft politics and diplomacy in order to accomplish specific goals. Furthermore, the ESDP framework has worked effectively in creating compatibility between the interests of the organization and its member states. Therefore, it is evident that the European Union has an autonomous, effective and active engagement with the international system.

Nonetheless, there are also implications regarding a self-directed EU which has become in a significant strategic actor. The most prominent one is the way in which a militarily impendent Europe is eroding the transatlantic relationship. From a positivistic point of view it could be argued that Europe, by acting as a rational actor, has different interests and concerns in contrast to the United States. This has created a vivid discourse among scholars, as many of them try to predict the outcome of this conflict, especially in regards to what will happen to NATO. In fact, in order for the North Atlantic alliance to survive it will have to unearth way in which it will have to modify its mandate in two ways. First, it will have to be able to satisfy the interests of the two divorcees; and secondly it has to become more active in order to be relevant to both Europe and the United States. Despite of what happens with NATO in the years to come, thanks to the ESDP the European Union has entered the international arena as one of the most significant international security actors of the $21^{\text {st }}$ century. 


\section{Bibliography}

Arrow, Kenneth J. "Economic theory and the hypothesis of rationality," The New Palgrave: A Dictionary of Economics, New York: Stockton Press, 1987

Baldwin, David A. (ed.). "Institutionalist Theory and the Realist Challenge After the Cold War." Neorealism and Neoliberalism: The Contemporary Debate, New York: Columbia University Press, 1993

Barnett, M. N. \& Finnemore, M. “The Politics, Power and Pathologies of International Organizations." International Organization. 53:4. MIT Press, 1999

Biscop, Sven. Euro-Mediterranean Security: A Search for Partnership. Asgathe Publishing Ltd. England. 2003

Bronstone, Adam. European Security into the Twenty-first Century: Beyond tradional theories of international relations. Asgathe Publishing Ltd. England, 2000

Cahen, Alfred. The Western European Union and NATO: Building a European Defence Identity within the Context of Atlantic Solidarity. Brassey's Ltd. London, 1989

Caporaso, J. "Regional integration theory: understanding our past and anticipating our future." Journal of European Public Policy, 5:1, Routledge, 1998

Cooper, Robert. "The European Answer to Robert Kagan.” Transatlantic Internationale Politik. 2. 2003

Carpenter, Gallen. Beyond NATO: Staying out of Europe's Wars. Cato Institute. Washington. 1994

Den Boer, Monica. \& Monar, Jörg. "Keynote Article: 11 September and the Challenge of Global Terrorism to the EU as a Security Actor," JCMS: Journal of Common Market Studies 40 (s1), Blackwell Publishing - UACES, 2002

Dorman, Andrew. M \& Treacher, Adam. European Security: An Introduction to Security Issues in Post-Cold War Europe. Darmouth Publishing Company. Cambridge. 1995

Ekengren, Magnus. "From a European security community to a secure European community.” CFSP Forum. Vol. 3. January 2005

Gegout ,Catherine \& Fellow, Marie C. "Europe has a strategy, but is the EU a strategic actor?” CFSP Forum Vol. 3. January 2005

Gieregich, Bastian. \& Wallace, William. "Not Such a Soft Power: The External Deployment of European Forces,” Survival, Vol. 46. No. 2, Summer 2004

Gordon, Philip. H. “Europe’s Uncommon Foreign Policy.” International Security. Vol. 22. No. 3. MIT Press. 1997 
Harries, Owen. "The Collapse of the West," Foreign Affairs. Vol. 72. Council on Foreign Relations, 1993.

Holm, Erik. The European Anarchy: Europe's Hard Road into High Politics, Copenhagen Business School Press, 2001

Holsti, K. J. The Dividing Discipline: Hegemony and Diversity in International Theory. Winchester, Massachusetts, Allen and Unwin, 1985

Hunter, Robert E. The European Security and Defense Policy: NATO's Companion or Competitor. Rand. Santa Monica. 2002

Jackson, Robert \& Sørensen Georg. Introduction to International Relations. Oxford University Press. New York. 1999

Keane, Rory. "European Security and Defence Policy: From Cologne to Sarajevo." Global Society, Vol. 19, No. 1, January 2005

Kagan, Robert. "Power and Weakness.” Policy Review. No. 113. June 2002

Leiken, Robert S. “Europe’s Angry Muslims.” Foreign Affairs. Vol. 84. July/August, Council on Foreign Relations, 2005

Martin, L. \& Simmons, B. "Theories and Empirical Studies of International Institutions.” International Organization. 54:2. MIT Press, 1998

McCormick, John. Understanding the European Union: A Concise Introduction. Palgrave Macmillan, 2005

Missorili, Antonio. Background of ESDP (1954-1999). Institute for Security Studies European Union. 2004

Menon, Anand, "From Crisis To Catharsis: The ESDP after Iraq." International Affairs, Vol. 80. No. 4, the Royal Institute of International Affairs, 2004

Neack, Laura. "Peacekeeping, Bloody Peacekeeping," Bulleting of the Atomic Scientists. Volume 60, Number 4. July/August, Bulleting of the Atomic Scientists, 2004

Williams, Phil ."Transnational Criminal Organisations and International Security," Survival, Vol. 36, No. 1, Spring, Oxford University, 1994 